解 説

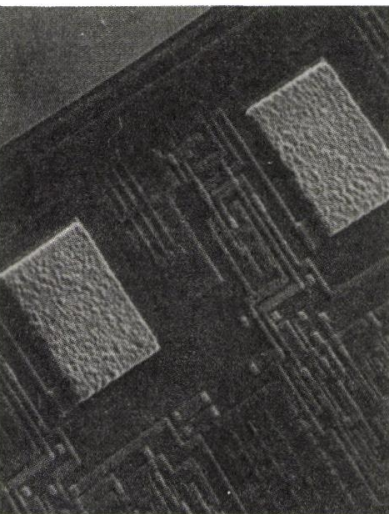

\title{
コンデンサ内蔵低温焼成多層 セラミック基板
}

Low Temperature Co-fired Multilayer Ceramic

Substrate with Enbedded Capacitors

$\begin{array}{llr}\text { 中井 菜一* } & \text { 柴田 } & \text { 清人* } \\ \text { 川南 修一* } & \text { 高橋 } & \text { 繁* }\end{array}$

1.はじめに

近年，半導体集積回路の技術進歩によりもたらされた 電子機器の高機能化・小型化の流れは，チップ部品や基 板を含めた実装技術の進歩を取り込んで新たなステップ へさしかかってきた。ハイブリッド ICでは，もともと基 板表面に厚膜抵抗を形成し，高機能化と実装点数の低減 等による信頼性面での特徴を有していた。低温焼成多層 セラミック基板は,このハイブリッドICの進化型とし て登場し, 多層化および抵抗・コンデンサ等の内蔵化に より小型化・高機能化をさらに推し進める武器として期 待を集めている。

当社では，1989 年に抵抗・コンデンサ内蔵多層セラミ ック基板 ( $\mathrm{RC}$ 基板) を上市し, 現在まで基板材料の他に コンデンサ材料の多品種化等を図ってきた。以下に RC 基板の概要と内蔵コンデンサの特徴について述べる。
用できるように, $850^{\circ} \mathrm{C}$ で焼成可能な $\mathrm{SiO}_{2}-\mathrm{B}_{2} \mathrm{O}_{3}-\mathrm{ZnO}$ $\mathrm{PbO}-\mathrm{CaO}$ 系ガラスーアルミナ複合組成を用いた。特に, ガラスとアルミナ各々の粒径および量は，基板の焼結性 に大きく影響を及ぼす。また焼成した基板は, $\mathrm{ZnAl}_{2} \mathrm{O}_{4}$ の 結晶相が析出するため, 再焼成による基板の軟化が少な く，絶縁特性もすぐれている。

内部導体には, 配線用とコンデンサ電極用の 2 種類の $\mathrm{Ag}$ ペーストを用いている。配線用 $\mathrm{Ag}$ ペーストについて は, 使用する球形 $\mathrm{Ag}$ 粉末 ( $1 \mu \mathrm{m}$ 程度) が約 $400^{\circ} \mathrm{C}$ で収 縮を始めるのに対して, グリーンシートの収縮は $700^{\circ} \mathrm{C}$ 前後である。そのため, ペースト化に際してはフリット ガラス等を適量加えることにより，収縮の夕イミングと 量の制御を行った。

一方, コンデンサ電極用 $\mathrm{Ag}$ ペース卜は, 基板のみなら ず誘電体とのマッチングも考慮しなければならない。 $\mathrm{Ag}$ 導体が基板より早く収縮する場合は，両者間でのデラミ ネーションを引き起こす原因になる。逆に，収縮が遅い

\section{2. $\mathrm{RC}$ 基板の概要}

\section{1 構造および材料}

$\mathrm{RC}$ 基板の断面構造を Fig.1 に示す。基板の 多層化方法として，グリーンシート積層法を 採用した。基板を構成するすべての材料は, その焼成温度が最高 $850^{\circ} \mathrm{C}$ であることを前提 に材料設計および開発を行った。

基板材料には，内部導体に $\mathrm{Ag}$ 系材料が使

\footnotetext{
* Kyouichi Nakai, Kiyohito Shibata, Shuichi Kawaminami, Shigeru Takahashi 日本セメント/Nihon Cement Co.,Ltd.
}

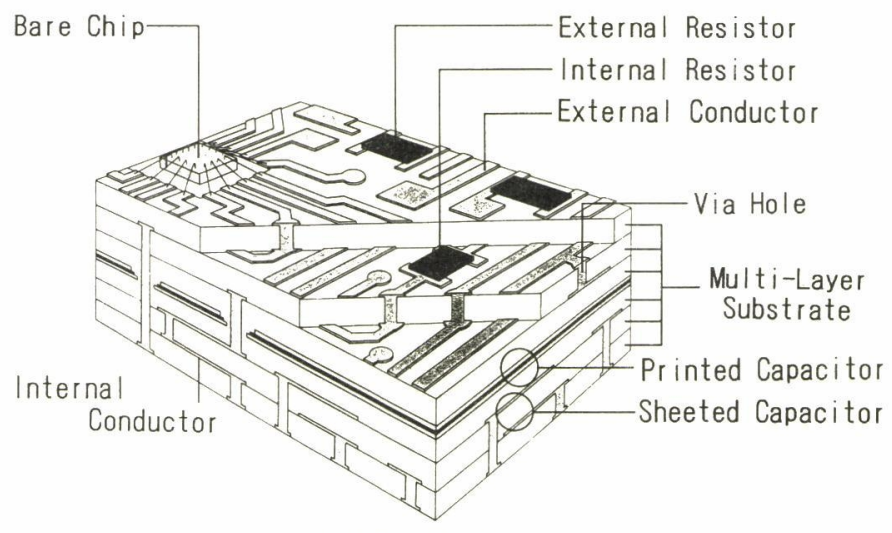

Fig.1 RC substrate,

$S H M$ 会誌 
Tab.1 Properties of RC substrate.

\begin{tabular}{|c|c|c|c|c|c|c|}
\hline Substrate & $\begin{array}{l}\text { Camber }(\mathrm{mm} / 75 \mathrm{~mm} \square) \\
\text { Surface roughness }(\mu \mathrm{m} / \mathrm{R} \\
\text { Flexural strength }\left(\mathrm{kg} / \mathrm{cm}^{2}\right. \\
\text { C.T.E. }\left(\times 10^{-6} /{ }^{\circ} \mathrm{C}\right) \\
\text { Thermal conductivity }(\mathrm{W} / \\
\text { Dielectric constant } \\
\text { Volume resistivity }(\Omega \cdot \mathrm{cm}) \\
\text { BDV }(\mathrm{kV} / \mathrm{mm})\end{array}$ & & \multicolumn{4}{|c|}{$\begin{array}{c}<0.15 \\
<0.6 \\
>2500 \\
7.0 \\
4.3 \\
7.8 \\
10^{14} \\
>15 \\
\end{array}$} \\
\hline \multirow[b]{2}{*}{ Conductors } & & & $\mathrm{Ag}$ & $\mathrm{Ag}-\mathrm{Pd}$ & $\mathrm{Ag}-\mathrm{Pt}$ & $\mathrm{Au}$ \\
\hline & $\begin{array}{l}\text { Line } / \text { Space }(\mu \mathrm{m}) \\
\text { Via-hole size }(\mu \mathrm{m}) \\
\text { Sheet resistance }(\mathrm{m} \Omega / \square) \\
\text { Peeling strength }(\mathrm{kg} / 2 \mathrm{~mm} \\
\text { Solderability }\end{array}$ & $\begin{array}{l}\text { Internal } \\
\text { External } \\
\text { Internal } \\
\text { External }\end{array}$ & $\begin{array}{l}\geqq 150 \\
\geqq 150 \\
4 \sim 6\end{array}$ & $\begin{array}{c}\geqq 180 \\
\\
25 \sim 35 \\
\geqq 1.5 \\
\text { Good }\end{array}$ & $\begin{array}{l}\geqq 180 \\
6 \sim 8 \\
\geqq 1.5 \\
\text { Good }\end{array}$ & $\begin{array}{l}\geqq 120 \\
\geqq 120 \\
\geqq 150 \\
4 \sim 6 \\
3 \sim 5\end{array}$ \\
\hline \multirow[b]{2}{*}{ Resistors } & & & \multicolumn{2}{|c|}{ Internal } & \multicolumn{2}{|c|}{ External } \\
\hline & $\begin{array}{l}\text { Resistance }(\Omega) \\
\text { Resistance tolerance (\%) } \\
\text { TCR }\left(\mathrm{ppm} /{ }^{\circ} \mathrm{C}\right)\end{array}$ & & \multicolumn{2}{|c|}{$\begin{array}{l}50 \sim 50 \mathrm{~K} \\
\leqq \pm 30 \\
\leqq \pm 200\end{array}$} & \multicolumn{2}{|c|}{$\begin{array}{l}6 \sim 3 \mathrm{M} \\
\leqq \pm 1 \\
\leqq \pm 150\end{array}$} \\
\hline
\end{tabular}

場合には，基板中のガラス成分が誘電体に拡散してコン デンサ容量を低下させる。したがって，適度なバランス を取ることが開発のポイントとなった1。

抵抗体は, 厚膜印刷法にて基板内部と外部両方に形成 することができる。特に内部抵抗については，現状トリ ミング不可能なため, 安定した抵抗值を得ることが要求 されている。抵抗ペースト中の抵抗值調整用がラスに基 板と同様ガラスを用いたことと, $\mathrm{RuO}_{2}$ 粉末の選定によっ て，実用可能なレベルの特性を有した内部抵抗ぺースト を開発した。

外部導体は，厚膜印刷法にて形成可能な $\mathrm{Ag}-\mathrm{Pd}, \mathrm{Ag}^{-}$ $\mathrm{Pt}, \mathrm{Au}$ が標準である。さらに微細配線対応として，フォ トリソグラフィ技術を用いた $\mathrm{Cu}$ および $\mathrm{Au}$ のパターニ ングも開発されている2。

\section{2 一般特性}

$\mathrm{RC}$ 基板の一般特性を $\mathrm{Tab} .1$ に示す。

\section{3. 内蔵コンデンサ}

コンデンサを基板に内蔵する方法として, 誘電体材料 を厚膜ペースト化し，グリーンシート上に印刷により形 成する方法と, 誘電体材料をグリーンシート化して基板 積層時に組み込み形成する方法とがある。いずれの方法 においても，技術的な課題は内蔵した誘電体材料と基板 材料，さらにそれらの間に介在する電極材料との相互の 反応の制御および収縮率のマッチングを調整することに

Vol.9, No.1
ある。

現在， $\mathrm{RC}$ 基板に内蔵できるコンデンサの種類として, 高容量コンデンサ・基板コンデンサおよび温度補償コン デンサの 3 種類が内蔵可能となっている。

以下に，高容量コンデンサと温度補償コンデンサにつ いて説明する。

\section{1 高容量コンデンサ}

\section{1 .1 材料および特性}

コンデンサ特性は, 電子回路におけるバイパスコンデ ンサとして使用可能な Y 5 U 特性を目標に, 誘電体材料 として RC 基板の焼成温度である $850^{\circ} \mathrm{C} て ゙$ 焼成可能な鉛 複合ペロブスカイト $\left[\mathrm{Pb}\left(\mathrm{Mg}_{1 / 3} \mathrm{Nb}_{2 / 3}\right) \mathrm{O}_{3}-\mathrm{PbTiO}_{3}-\mathrm{PbO}\right.$ 系）を使用した。この誘電体にエチルセルロースと溶剤 を添加して厚膜ペースト化し，印刷法でコンデンサを形 成する。

Tab.2 Property of dielectric.

\begin{tabular}{l|l|c}
\hline \multirow{4}{*}{ BulK } & Dielectric constant & 7500 \\
\cline { 2 - 3 } & $\tan \delta(\%)$ & 0.3 \\
\cline { 2 - 3 } & I.R. $(\Omega)$ & $2 \times 10^{11}$ \\
\cline { 2 - 3 } & Density $\left(\mathrm{g} / \mathrm{cm}^{3}\right)$ & 7.8 \\
\hline \multirow{5}{*}{ Capacitor } & Capacitance $\left(\mathrm{nF} / \mathrm{cm}^{2}\right)$ & 60 \\
\cline { 2 - 3 } & $\tan \delta(\%)$ & 1.0 \\
\cline { 2 - 3 } & I.R. $(\Omega)$ & 800 \\
\cline { 2 - 3 } & B.D.V. $(\mathrm{V})$ & $80^{10}$ \\
\hline
\end{tabular}




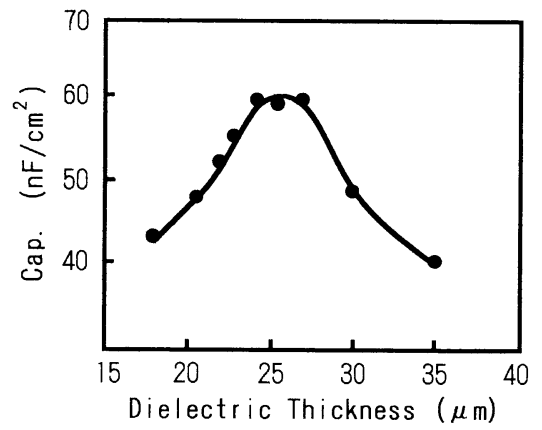

Fig. 2 Dielectric thickness vs. capacitance.

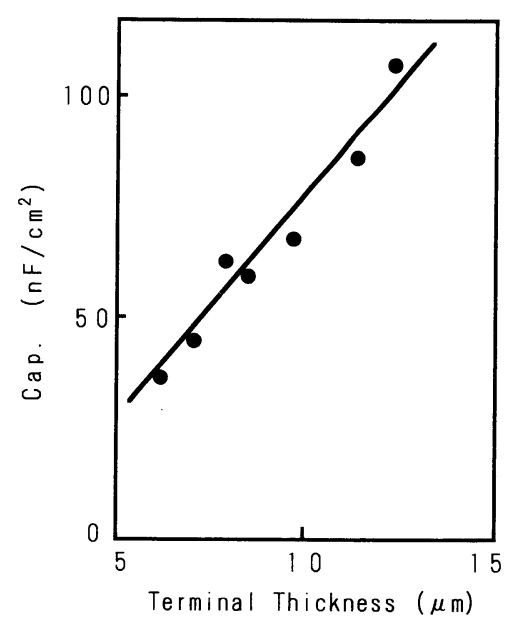

Fig.3 Terminal thickness vs. capacitance.

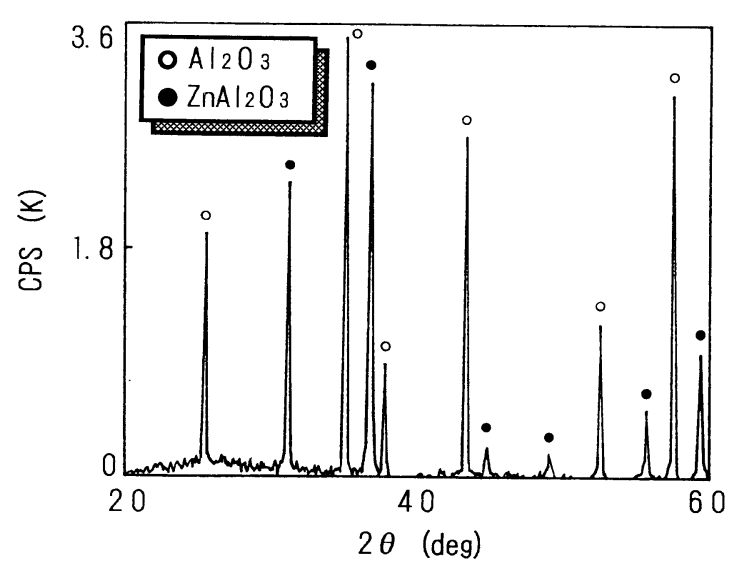

Fig. 4 XRD pattern of substrate.

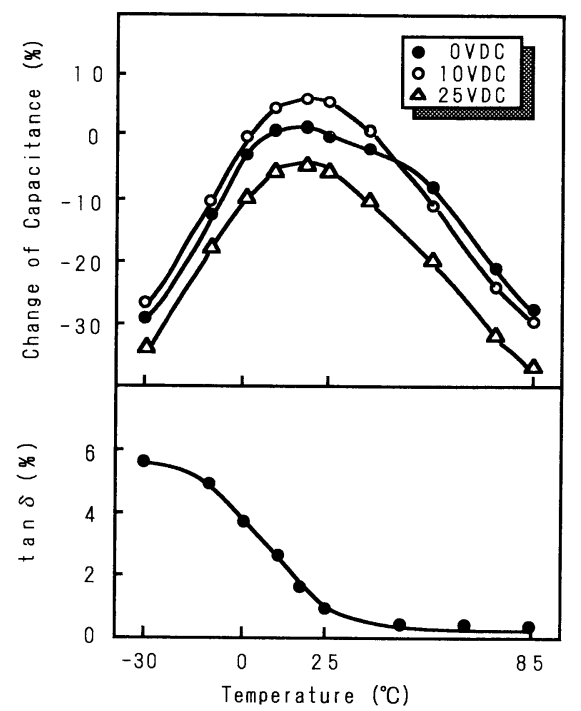

Fig.5 Capacitor's characteristics with temperature.

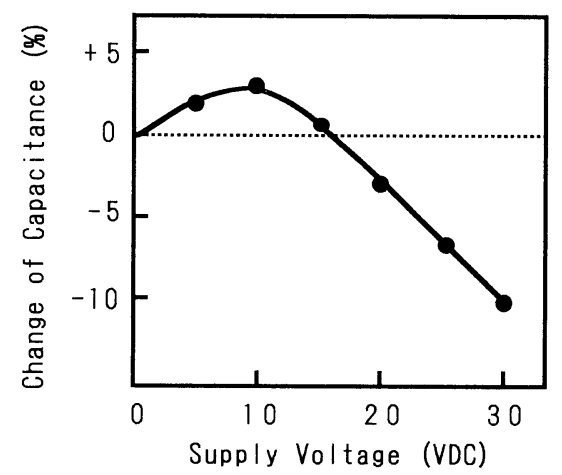

Fig.6 Supply voltage vs. change of capacitance.

Tab.2 に誘電体の Bulk 特性および基板内蔵時のコン デンサ特性を示す。基板内蔵時のコンデンサ容量バラツ キは, 主に誘電体および電極の印刷膜厚精度に依存して いる。Fig.2 に誘電体膜厚と容量の関係を示す。基板焼成 時のガラス成分の拡散による影響を受けやすい誘電体に おいて，その膜厚が薄くなると誘電率の低下がみられる ため, 容量は膜厚 $25 \mu \mathrm{m}$ 近傍で最大値をもつ。

また, Fig.3に電極膜厚と容量の関係を示す。電極膜厚 が厚いほど, 誘電体中へのガラスの拡散が抑制され, 容 量増加を示す。いずれの場合も，初期焼成におけるがラ スの拡散に比べ, 2 回目以降の焼成（外部導体や抵抗等 の焼成）ではガラスの拡散が抑制されることにより, 繰 り返し焼成における容量変化は小さい。これは，基板中 のガラスの一部が $\mathrm{ZnAl}_{2} \mathrm{O}_{4}$ スピネル結晶を生成するた めである。Fig.4に焼成基板のX線回折デー夕を示す。 
したがって，コンデンサ容量の精度を上げるためには, 誘電体および電極の印刷条件を管理することが製造上の ポイントとなる。

Fig.5にコンデンサの温度特性を示す。 $-30^{\circ} \mathrm{C} \sim 85^{\circ} \mathrm{C}$ の範囲で容量変化は+10\%〜 - $35 \%$ 以内であり, Y $5 \mathrm{U}$ 特性を充分満足している。

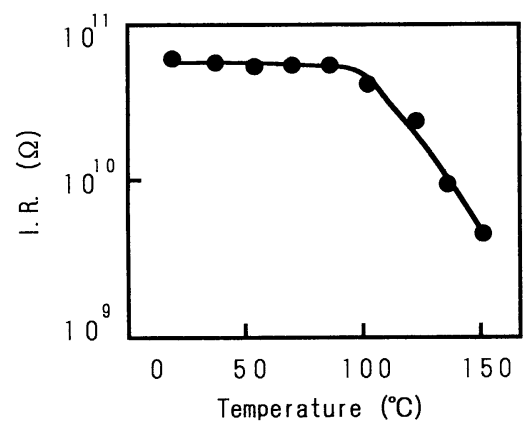

Fig.7 Insulation resistance with temperature.

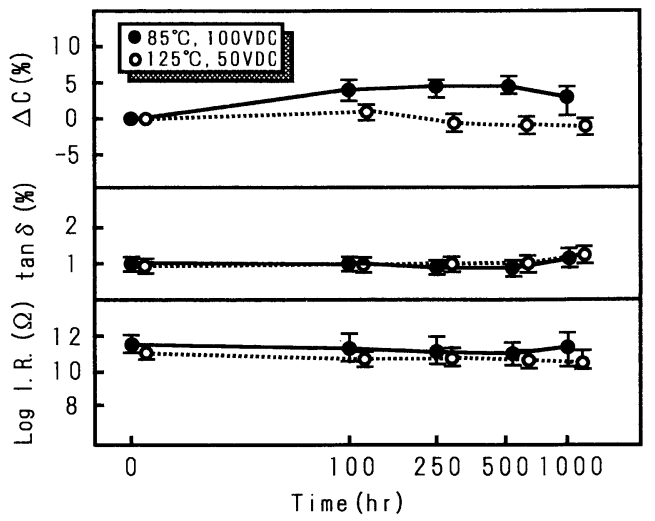

Fig. 8 Capacitor's characteristics after HBT.

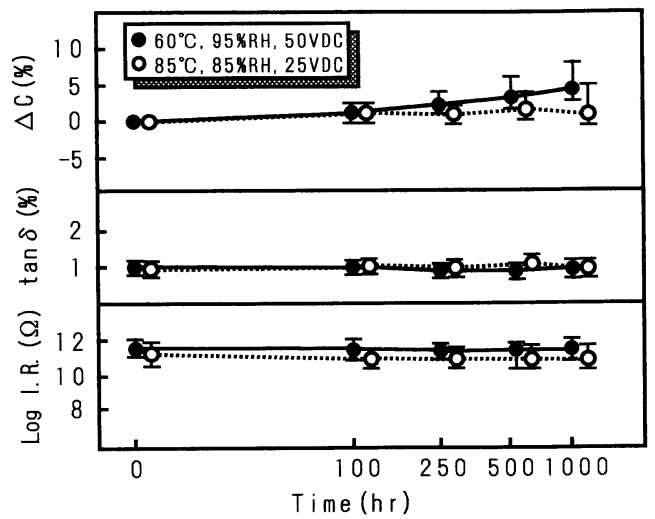

Fig.9 Capacitor's characteristics after HHBT. Vol.9, No.1
また，Fig.6には DCバイアス特性を，Fig.7にはI. R.の温度特性を示す。標準的なセラミックコンデンサと ほぼ同様な特性值を得ている。

\section{1 .2 信頼性}

Fig.8Ｆig.11に主な信頼性試験におけるコンデンサ 特性を示す。

\section{2 温度補償コンデンサ}

\section{2 .1 材料および特性}

一般に用いられる温度補償用コンデンサ材料は，すべ て $1,000^{\circ} \mathrm{C}$ 以上で焼成しており, $850^{\circ} \mathrm{C}$ で焼成可能な材料 はない。したがって, RC 基板材料と同思想で誘電体フィ ラーに基板材料と同じガラスを添加することで低温焼成 を可能にし，同時にガラス拡散の影響も極力抑えるよう な材料系を検討することにした。ここで問題となるのは， ガラスの添加により誘電体の初期特性がどの程度劣化す

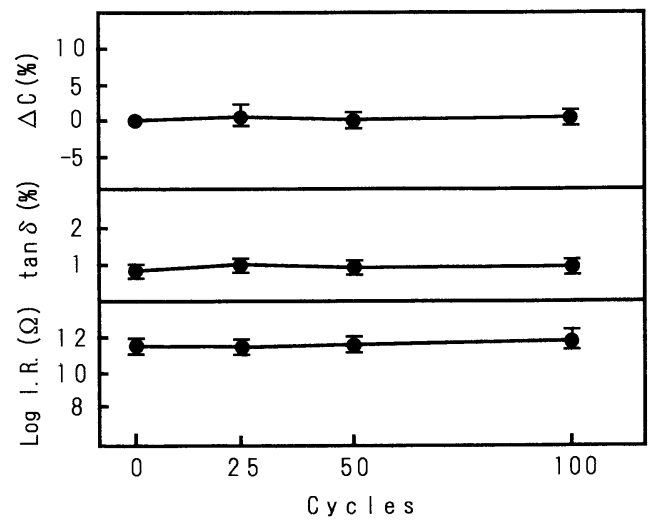

Fig.10 Capacitor's characteristics after temperature cycle test $\left(-55 \sim+125^{\circ} \mathrm{C}, 30 \mathrm{~min} . / \mathrm{step}\right)$.

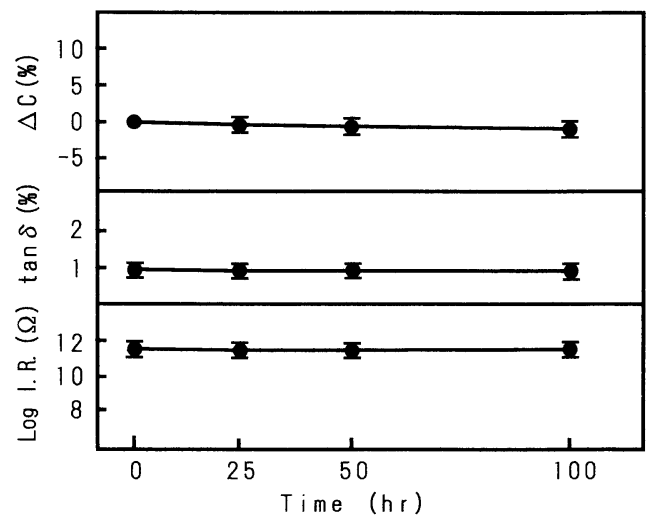

Fig.11 Capacitor's characteristics after PCT $\left(121^{\circ} \mathrm{C}, 2.1 \mathrm{~atm}, 100 \% \mathrm{RH}\right)$. 


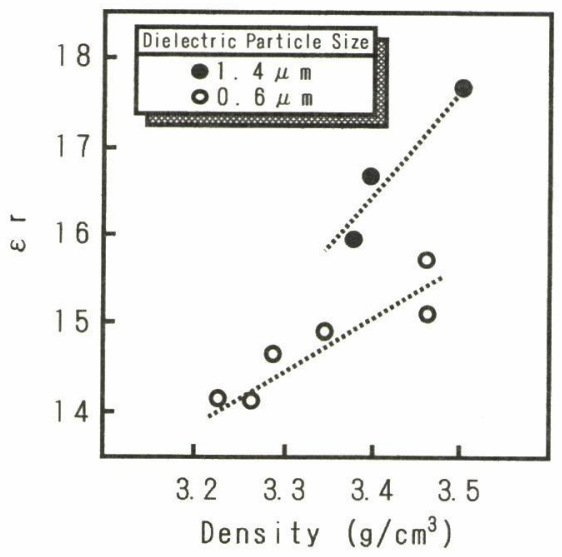

Fig.12 Sinterd density vs. dielectric constant.

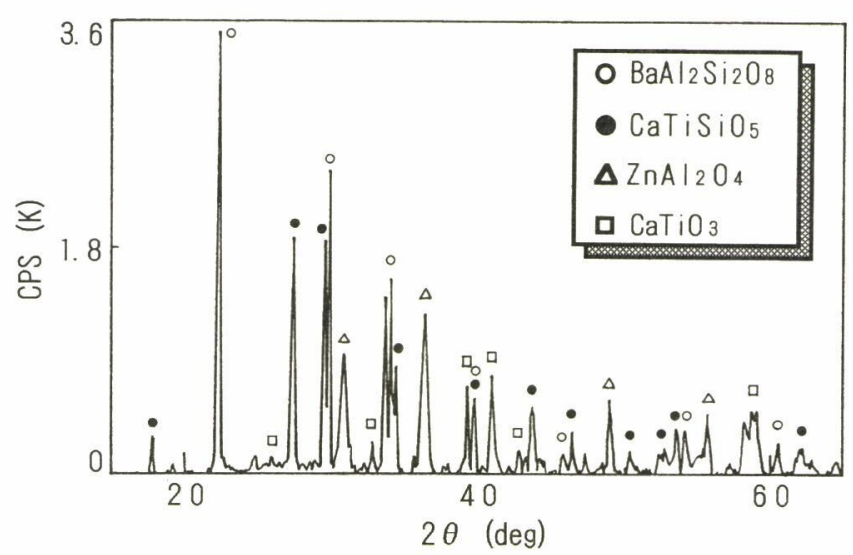

Fig.14 XRD pattern of dielectric.
るかであった。検討の結果, $\mathrm{CaTiO}_{3}$ を主成分とした $\mathrm{CaTiO}_{3}-\mathrm{BaTiO}_{3}$-ガラス系材料を使用することとした。 またコンデンサの形成方法は，容量制御が容易で，大面 積コンデンサが形成しやすい等の理由から，シート積層 法を採用した。

さらに，コンデンサ材料の特性改善を行うために，以 下の検討を行った。

\section{1）誘電体の焼成密度アップ}

誘電率および信頼性を向上させるためには，誘電体の 焼成密度を高めることが不可欠である。ひとつの方法と して, 誘電体フィラーとガラスの粒径を最適化すること

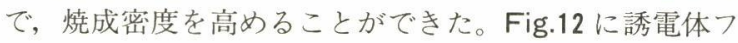
イラーの粒径の違いによる焼成密度と誘電率の関係を示 す。当然ながら焼成密度がアップすると誘電率も大きく なる。その他に誘電体フィラーを粗粉化すると誘電率が 增加し, 同時に TCC (コンデンサ温度係数) 值も大きく

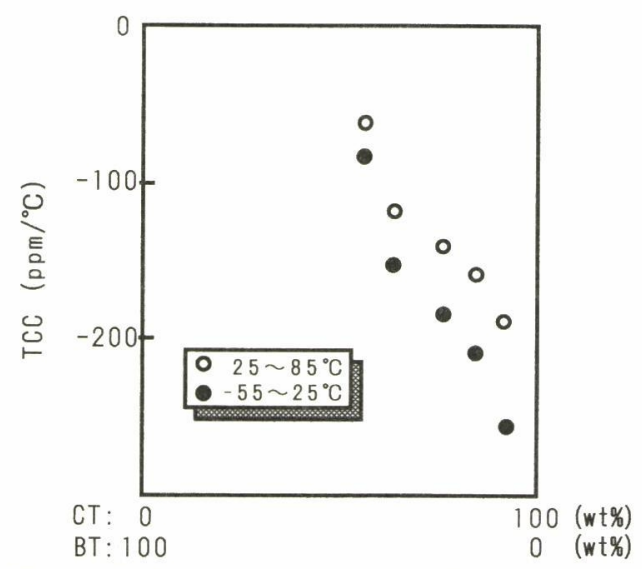

Fig.13 TCC by mixture ratio of $\mathrm{CaTiO}_{3}$ to $\mathrm{BaTiO}_{3}$. 28
変化する。このことは, X 線回折の結果より, 誘電体つ イラー中の $\mathrm{CaTiO}_{3}$ ががラス中の $\mathrm{SiO}_{2}$ と反応して $\mathrm{CaTiSiO}_{5}$ を生成することが影響していると考えている。 すなわち, $\mathrm{CaTiO}_{3}$ を粗粉化し, 焼成後の $\mathrm{CaTiO}_{3}$ の残量 を相対的に多くすることで, 誘電率は増加し, TCC は負 へ大きくシフトする $\left(\mathrm{CaTiO}_{3}\right.$ の $\varepsilon_{r}=150, \mathrm{CaTiSiO}_{5}$ の $\varepsilon_{r}=21$ )。

\section{2） TCCのコントロール}

負の TCC 特性を有する $\mathrm{CaTiO}_{3}$ に, $\mathrm{BaTiO}_{3}$ を混合す ることによって，TCCのコントロールを可能にした。

Tab.3 Property of dielectric.

\begin{tabular}{|c|c|}
\hline Dielectric constant & 15.4 \\
\hline Q & 1510 \\
\hline $\begin{aligned} \mathrm{TCC}\left(\mathrm{ppm} /{ }^{\circ} \mathrm{C}\right) & {\left[25 \sim 85^{\circ} \mathrm{C}\right] } \\
& {\left[-55 \sim 25^{\circ} \mathrm{C}\right] }\end{aligned}$ & $\begin{array}{l}-21.7 \\
-22.3\end{array}$ \\
\hline I.R. $(\Omega)$ & $1.1 \times 10^{13}$ \\
\hline
\end{tabular}

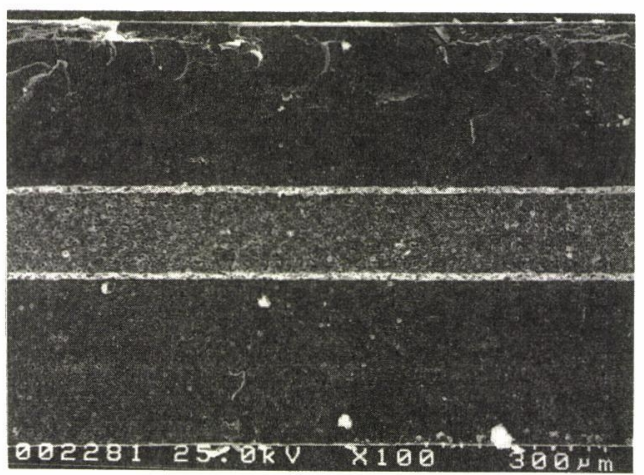

Fig.15 SEM cross-section of capacitor

$S H M$ 会誌 
Fig.13 に $\mathrm{CaTiO}_{3}$ と $\mathrm{BaTiO}_{3}$ の比と $\mathrm{TCC}$ の関係を示す。 また強誘電体である $\mathrm{BaTiO}_{3}$ を加えているにもかかわら ず, 誘電率の著しい増加がみられなかったのは, 焼成時 における反応生成物による影響と考之られる。Fig.14に 誘電体焼成後の X 線回折チャートを示す。

最終決定した誘電体組成にて, グリーンシート化の検 討を行った。得られたグリーンシートは, シート成形お よび基板作製において，現有の製造ラインでの製造が可 能である。また, 誘電体にもともと基板材料と同じガラ スを添加しているため, ガラスの拡散による影響を気に することなく，コンデンサ電極として配線用導体を用い

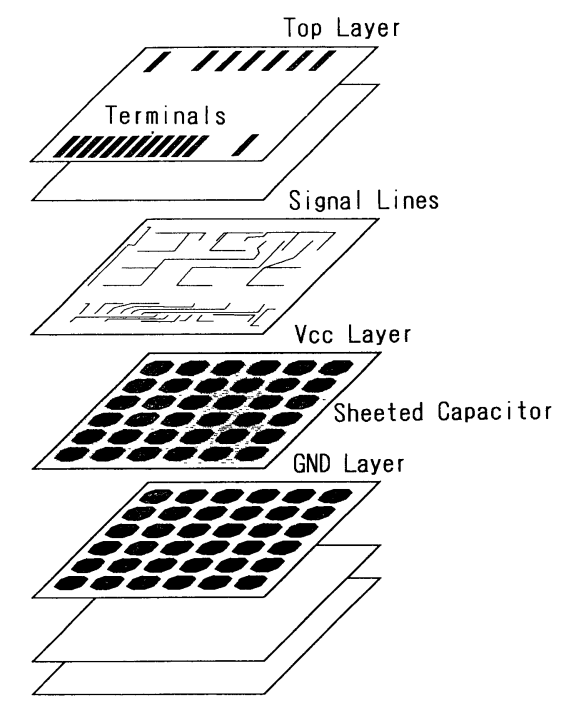

Fig.16 Structure of reliability test substrate.

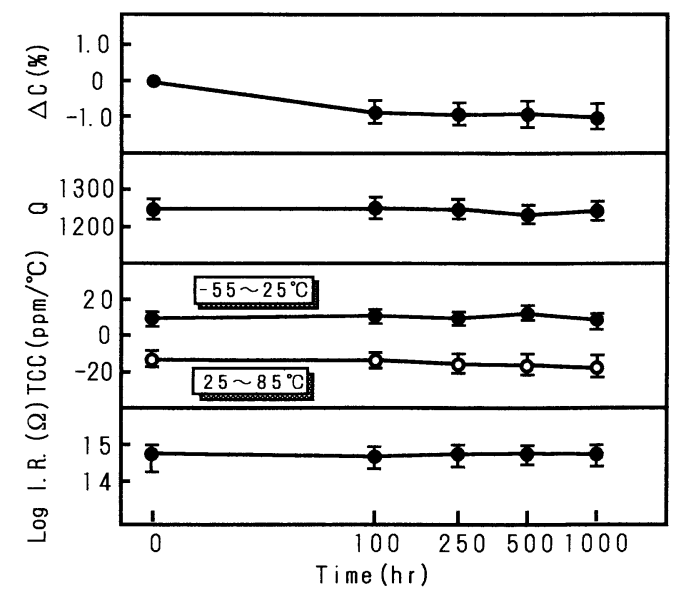

Fig.17 Capacitor's characteristics after HBT $\left(150^{\circ} \mathrm{C}, 250 \mathrm{VDC}\right)$.
ることができる。そのため，基板-電極-コンデンサ間の デラミネーションに対する信頼性も向上している。

Tab.3 にコンデンサ特性を示す。また, Fig.15 にコンデ ンサ部断面の SEM 写真を示す。

\section{2 .2 信頼性}

Fig.16に温度補償コンデンサ信頼性試験基板の構成困 を示す。この基板は 7 層構造を有し，4 層目に温度補償 コンデンサシートが組み込まれ，その上下にコンデンサ の電極を形成し合計 36 個のコンデンサが内蔵される。

Fig.17〜18 に主な信頼性試験におけるコンデンサ特性を 示す。

また各信頼性試験が終了した試料の BDV を測定した ので, 結果を Fig.19に示す。

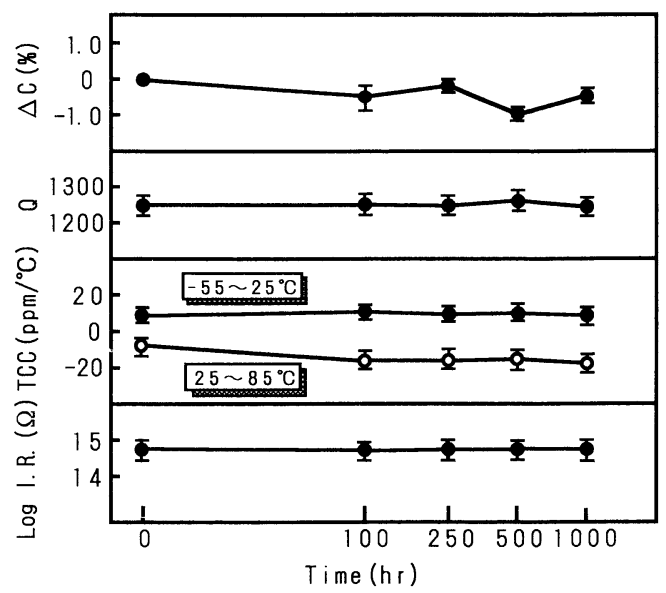

Fig. 18 Capacitor's characteristics after HHBT $\left(85^{\circ} \mathrm{C}, 85 \% \mathrm{RH}, 250 \mathrm{VDC}\right)$.

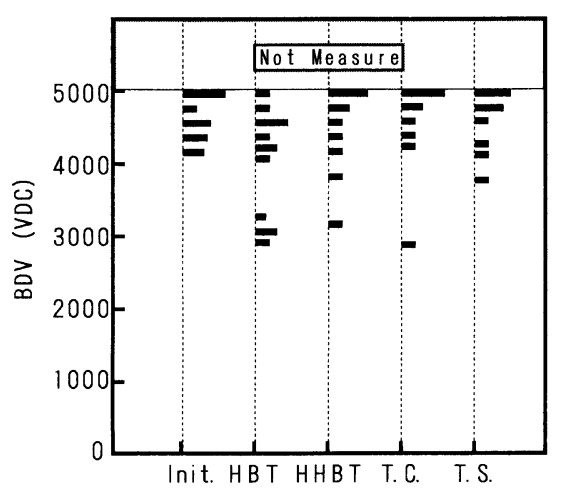

Fig.19 BDV after reliability tests.

Vol.9, No.1 


\section{4.おわりに}

以上述べてきたように，低温焼成多層セラミック基板 に多種類のコンデンサを内蔵することが可能になり，抵 抗体も含めた高機能配線基板へのさらなるステップアッ プが実現できた。

今後も, $\mathrm{RC}$ 基板の特徴を活かすことが可能な市場で の要求に対応していくために, さらに多くの部品や機能 を基板に取り込むための材料開発およびプロセス開発を 推し進めていくとともに, 安定した品質確保およびコス 卜低減等にも注力していく。

また，この種の基板の標準化を他社メーカとの協調の もとで推し進めていくことにより，ユーザにとって，よ り使い易い基板を提供することがメーカ側の責任である と考えている。

\section{参 考 文 献}

1）川南修一, 久保田 雅, 上赤日出人：第 3 回マイクロエ レクトロニクスシンポジウム (MES'89), p.54 (1989)

2) J.Asaumi, K.Nakai, T.Ezaki, O.Sugano, S.Takahashi and C.Yamagishi : ISHM'91 Proceedings, Orlando, p.402 (1991)

\section{【執筆者紹介〕 \\ 中井恭一（なかいきょういち）当協会正会員}

昭和 59 年岩手大学工学部資源化学科卒業。同年日通工(㑣)入 社，八イブリッド ICの開発に従事。平成元年日本セメント(株) 入社。以来, 低温焼成セラミック基板の開発に従事。現在, 中 央研究所新材料研究部勤務。

柴田清人（しばたきよひと）

昭和 60 年千葉大学理学研究科修士課程修了。同年(侏村田製作 所入社，フェライトの開発に従事。昭和 62 年日本セメント(侏) 入社。以来, 低温焼成セラミック基板の開発に従事。現在，中 央研究所新材料研究部勤務。

川南修一（かわみなみしゅういち）当協会正会員

昭和 57 年名古屋工業大学工学研究科修士課程修了。同年京七 ラ(侏入社, セラミックコンデンサの開発に従事。昭和 62 年日 本セメント(株入社。以来, 低温焼成セラミック基板の開発に従 事。現在，開発本部電子技術センター勤務。

高橋 繁（たかはししげる）当協会正会員

昭和 42 年上智大学理工学部卒業。同年東光秼入社。以来, 電 子材料関連開発に従事。昭和 63 年日本セメント(梀入社。以 来, 低温焼成セラミック基板の開発に従事。現在，中央研究所 新材料研究部主席研究員。 